\title{
Hubungan antara konsep diri dan adversity quotient dengan kecemasan menghadapi masa depan remaja jalanan
}

\author{
Ira Dwiyati Harahapa,1, Dessy Pranungsarib,2* \\ aPT. Inti Terang Sukses, Tebing Tinggi \\ bFakultas Psikologi, Universitas Ahmad Dahlan, Yogyakarta \\ 1dwiyirah@gmail.com; *2dessy.pranungsari@psy.uad.ac.id \\ *Correspondent Author
}

\section{KAT A KUNCI}

adversity quotient;

kecemasan menghadapi masa depan;

konsep diri

\section{KEYWORDS}

adversity quotient; anxiety facing the future self-concept
ABSTRAK

Rendahnya kesejahteraan pada remaja menyebabkan banyaknya masalah sosial, salah satunya adalah anak jalanan. Penelitian ini bertujuan untuk mengetahui hubungan konsep diri dan adversity quotient dengan kecemasan menghadapi masa depan pada remaja jalanan. Metode yang digunakan dalam penelitian ini adalah metode penelitian kuantitatif. Alat pengumpulan data menggunakan skala konsep diri, skala adversity quotient, dan skala kecemasan menghadapi masa depan. Subjek penelitian ini adalah remaja jalanan di bawah dampingan LSM Rumah Impian Yogyakarta yang berjumlah 40 orang. Hasil koefisien regresi berganda antara konsep diri dan adversity quotient dengan kecemasan menghadapi masa depan menunjukkan korelasi $\mathrm{R}=0,666$ dengan taraf signifikansi $\mathrm{p}=0,000$ $(\mathrm{p}<0,00)$. Hal ini berarti ada hubungan yang sangat signifikan antara konsep diri dan adversity quotient dengan kecemasan menghadapi masa depan pada remaja jalanan. Hasil koefisien korelasi antara konsep diri dengan kecemasan menghadapi masa depan adalah sebesar $r=-0,597$, dengan taraf signifikansi $p=0,000(p<0,01)$. Artinya semakin tinggi konsep diri maka akan semakin rendah kecemasan menghadapi masa depan. Hasil koefisien korelasi adversity quotient antara konsep diri dengan kecemasan menghadapi masa depan adalah sebesar $r=-0,634$, dengan taraf signifikansi $p=0,000(p<0,01)$. Artinya semakin tinggi adversity quotient maka akan semakin rendah kecemasan menghadapi masa depan. Sumbangan efektif variabel konsep diri terhadap kecemasan menghadapi masa depan sebesar $17,34 \%$, dan sumbangan adversity quotient terhadap kecemasan menghadapi masa depan sebesar 26,92\%. Kesimpulan penelitian menunjukan semakin tinggi konsep diri dan adversity quotient maka akan semakin rendah kecemasan menghadapi masa depan. Begitu pula sebaliknya, semakin rendah konsep diri dan adversity quotient maka semakin tinggi kecemasan menghadapi masa depan.

\section{The relationship between self-concept and adversity quotient with anxiety facing the future of street youth}

The low welfare of adolescents causes many social problems, one of which is street children. This study aims to determine the relationship of self-concept and adversity quotient with anxiety for the future on homeless youth. The method used in this research is quantitative method. This study uses data collection tools using self-concept scale, scale Adversity quotient, and the scale of anxiety for the future. Subjects 
in this study were young street below NGOs assisted Dream Home Yogyakarta totaling 40 people. Analysis technique used is multiple regression analysis with SPSS 16.0 for Windows. The results of multiple correlation self-concept and adversity quotient with anxiety for the future show a correlation $R=0.666$ with a significance level of $p=0.000$ $(p<0.00)$. This means there is a significant relationship between selfconcept and adversity quotient with anxiety for the future on homeless youth. The correlation coefficient between self-concept and anxiety for the future premise significance level of $p=0.000 \quad(p<0.01)$ and the correlation coefficient $r=-0.597$. This means that the higher self-concept the lower the anxiety for the future. The correlation coefficient of adversity quotient themselves with anxiety for the future premise significance level of $p=0.000(p<0.01)$ and a correlation coefficient of $r=-$ 0.634 . Adversity quotient means that the higher the lower the anxiety for the future. The conclusion of the study shows that the higher the selfconcept and adversity quotient, the lower the anxiety facing the future. Vice versa, the lower the self-concept and adversity quotient, the higher the anxiety facing the future.

This is an open-access article under the CC-BY-SA license.

\section{Pendahuluan}

Masa remaja adalah suatu masa dalam hidup manusia yang banyak mengalami perubahan (pancaroba) yaitu masa peralihan dari anak-anak menuju dewasa, tanpa batasan usia yang jelas. Menurut Monks (2002) remaja dikategorikan dalam rentang umur 12-23 tahun. Secara biologis maupun kultural masa remaja dipandang sebagai akhir sebelum masa dewasa. Masa ini ditandai oleh berbagai aktivitas dan perubahan besar, dan juga merupakan tahapan individu dalam mengembangkan identitas dirinya (Salkind, 2008).

Banyak faktor yang dapat membantu remaja dalam menjalankan tugas perkembangannya, salah satu faktor tersebut adalah kesejahteraan, Namun hal yang disayangkan bahwa tidak semua remaja memiliki hidup yang cukup sejahtera. Rendahnya tingkat kesejahteraan menyebabkan banyaknya masalah sosial, salah satunya adalah anak jalanan. Seperti halnya yang disampaikan oleh Dinas Sosial kota Yogyakarta (2016), bahwa faktor-faktor yang menyebabkan lahirnya anak jalanan diantaranya adalah kondisi krisis perekonomian negara yang menyebabkan orang tua mendorong anaknya untuk membantu ekonomi, serta anak putus sekolah karena orang tua tidak mampu membayar uang sekolah. Remaja memiliki tugas perkembangan dan kebutuhan yang berbeda dari masa anak ataupun masa dewasa. Apabila tugas dan kebutuhan dapat terpenuhi, maka membawa kebahagiaan dan kesuksesan dalam rentang kehidupan remaja. Sebaliknya apabila gagal, maka akan menyebabkan ketidakbahagiaan pada remaja yang bersangkutan, menimbulkan penolakan masyarakat, dan kesulitan-kesulitan dalam menuntaskan tugas-tugas perkembangan periode-periode berikutnya (Putro, 2017).

Selanjutnya, pada saat masa depan masih menjadi angan-angan dan menjadi sesuatu yang belum diyakini, akan dapat menimbulkan banyak masalah, salah satunya kecemasan (Wahyuni, 2013). Menurut Halgin (2010) kecemasan merupakan kondisi yang berorientasi pada masa depan dan bersifat umum, mengacu pada kondisi ketika individu merasakan kekhawatiran atau kegelisahan, ketegangan, dan rasa tidak nyaman yang tidak terkendali mengenai kemungkinan akan terjadinya sesuatu yang buruk. Sementara masa depan dapat dilihat sebagai suatu harapan atau ancaman. Ketika dianggap sebagai suatu ancaman dapat 
memunculkan adanya kekhawatiran, ketakutan dan tekanan-tekanan yang pada akhirnya menyebabkan kecemasan, ketidakpastian dan gambaran tentang masa depan masih seperti sebuah angan-angan, remaja jalanan dapat mengalami banyak kecemasan pada saat menjalankan tugas perkembangannya (Zaleski dalam Wahyuni, 2013).

Salah satu faktor yang dapat menekan kecemasan menghadapi masa depan adalah konsep diri. Burns (1993) menyatakan bahwa konsep diri adalah satu gambaran yang kita pikirkan, pikiran atau pendapat orang lain mengenai diri kita, dan gambaran diri kita yang kita inginkan. Apabila remaja memandang dirinya dengan positif, maka akan memiliki motivasi pada dirinya sendiri, dan akan berpikir ia mampu dan akan mewujudkan mimpinya, sehingga dapat mengurangi kecemasan yang dihadapinya.

Selain itu terdapat pula adversity quotient yang dapat mengurangi kecemasan dalam menghadapi masa depan remaja jalanan (Wahyuni, 2013). Slotz (2008) menyatakan bahwa adversity quotient adalah daya juang. Adversity quotient memiliki peran dalam menurunkan tingkat kecemasan pada remaja jalanan, karena remaja jalanan yang memiliki daya juang tinggi dan tidak mudah berputus asa pada halangan dan masalah yang dihadapinya, serta akan terus berjuang demi mencapai keinginannya.

Hasil penelitian terdahulu yang dilakukan oleh Wahyuni (dalam Wahyuni, 2013) pada remaja anak jalanan yang tinggal di lingkungan pondok sosial (LIPONSOS) Wonorejo Surabaya, meunjukkan adanya hubungan negatif antara adversity quotient dengan kecemasan menghadapi masa depan. Berdasarkan hasil ini dapat dilihat bahwa semakin tinggi adversity quotient maka akan semakin rendah kecemasan menghadapi masa depan, dan sebaliknya semakin tinggi kecemasan menghadapi masa depan maka akan semakin rendah adversity quotient.

Berdasarkan penjabaran di atas memperlihatkan bahwa kecemasan menghadapi masa depan pada anak jalanan penting untuk diangkat agar dapat diketahui faktor apa saja yang mampu menurunkan kecemasan tersebut. Dengan demikian hasil penelitian ini diharapkan mampu menjadi antisipasi bagi Lembaga masyarakat yang bersentuhan langsung dengan anak jalanan dalam rangka mempersiapkan anak jalanan seperti remaja lainnya dalam menghadapi masa depan. Berdasarkan hal tersebut, maka tujuan dari penelitian ini adalah ingin melihat hubungan konsep diri, adversity quotient dengan kecemasan menghadapi masa depan. Hipotesis dalam penelitian ini adalah ada hubungan antara konsep diri dan adversity quotient dengan kecemasan menghadapi masa depan remaja jalanan.

\section{Metode}

Penelitian ini menggunakan metode penelitian kuantitatif. Pengambilan subjek pada penelitian ini menggunakan teknik non random sampling yang artinya setiap individu atau unit yang diambil dengan sengaja menurut ketentuan tertentu. Subjek yang digunakan dalam penelitian ini merupakan remaja jalanan di bawah naungan LSM Rumah Impian. Subjek berjumlah 40 orang, dengan usia 11-21 tahun, dan berdomisili di DIY.

Alat pengumpulan data yang digunakan pada penelitian ini adalah skala untuk mengungkap aspek psikologi kepada individu. Alat pengumpulan data menggunakan tiga skala yaitu (1) skala konsep diri (2) adversity quotient (3) kecemasan menghadapi masa depan. Skala yang dibuat merupakan skala sikap model Likert. Azwar (2012) menjelaskan skala sikap disusun untuk mengungkap sikap pro dan kontra, positif dan negatif, setuju dan tidak setuju terhadap suatu objek. Pada skala sikap objek sosial tersebut berlaku sebagai objek sikap. Skala sikap berisi pernyataan-pernyataan sikap (attitude statements), yaitu suatu pernyataan mengenai objek sikap.

Skala kecemasan menghadapi masa depan dibuat berdasarkan aspek-aspek menurut Kendal dan Harmen (1998), meliputi aspek kognitif, aspek afektif, aspek fisiologis, dan aspek perilaku. Berdasarkan analisis uji coba dan seleksi aitem, didapatkan 28 aitem dengan 
korelasi aitem total (rit) terendah 0,289 dan (rit) 0,564. Berdasarkan hasil analisis koefisien reliabilitas alpha, diperoleh koefisien reliabilitas alat ukur sebesar 0,859 yang berarti bahwa alat ukur tersebut reliabel dan dapat digunakan sebagai alat ukur yang memadai dalam pengumpulan data penelitian

Skala konsep diri disusun berdasarkan aspek-aspek konsep diri menurut Hurlock (1993), yang meliputi gejala fisik yang meliputi tentang penilaian terhadap penampilan beserta barang-barang yang dimilikinya, kemampuan fisik dan daya tarik yang dimilikinya, arti penting tubuhnya, cara orang lain memandangnya, dan aspek psikologis meliputi penilaian individu terhadap psikisnya, rasa percaya diri, penerimaan dirinya (kemampuan dan ketidak mampuannya), harga dirinya, hubungannya dengan orang lain. Berdasarkan analisis uji coba dan seleksi aitem skala konsep diri didapatkan 40 aitem dengan korelasi aitem total (rit) terendah 0,269 dan korelasi aitem total (rit) tertinggi sebesar 0,597. Berdasatkan hasil analisis koefisien reliabilitas alpha, diperoleh koefisien reliabilitas alat ukur sebesar 0,895 yang berarti bahwa alat ukur tersebut reliabel dan dapat digunakan sebagai alat ukur yang memadai dalam pengumpulan data penelitian.

Selanjutnya, skala adversity quotient ini disusun berdasarkan dimensi menurut Slotz (2000), meliputi dimensi control (pengendalian), origin dan ownership (kepemilikan), reach (jangkauan), dan endurance (daya tahan). Berdasarkan hasil analisis uji coba dan seleksi aitem skala adversity quotient didapatkan 38 aitem dengan korelasi aitem total (rit) terendah 0,389 dan korelasi aitem total (rit) tertinggi 0,684. Berdasarkan hasil analisis koefisien reliabilitas alpha diperoleh indeks reliabilitas alat ukur sebesar 0,922 yang berarti bahwa alat ukur tersebut reliabel dan dapat digunakan sebagai alat ukur yang memadai dalam pengumpulan data penelitian.

Teknik analisis data yang digunakan adalah analisis regresi berganda, karena penelitian ini menguji hipotesis hubungan anatara dua variabel bebas dan satu variabel tergantung. Sebelum dilakukan analisis data, terlebih dahulu dilakukan uji asumsi. Analisis data dalam penelitian ini menggunakan bantuan komputasi statistik dengan program SPSS versi 16.0 for Windows.

\section{Hasil}

Berdasarkan hasil analisis data diketahui bahwa besarnya koefisien regresi antara variabel konsep diri dan adversity quotient dengan kecemasan menghadapi masa depan remaja jalanan diperoleh skor $\mathrm{R}=0,666$ dengan niai $\mathrm{p}=0,000(\mathrm{p}<0,01)$. Artinya, ada hubungan positif yang sangat signifikan antara konsep diri, adversity quotient, dan kecemasan menghadapi masa depan. Berdasarkan hasil analisis korelasi parsial diketahui bahwa besarnya nilai koreasi rx1y=-0,597 dengan nilai $p=0,000(p<0,01)$ hal ini menunjukkan bahwa terdapat hubungan negatif yang sangat signifikan antara variabel konsep diri dengan kecemasan menghadapi masa depan. Semakin rendah konsep diri maka semakin tinggi kecemasan menghadapi masa depan remaja jalanan, begitu pula sebaliknya semakin positif konsep diri maka semakin rendah kecemasan menghadapi masa depan remaja jalanan.

Hasil analisis selanjutnya adalah untuk mengetahui hubungan anatara variabel adversity quotient dengan kecemasan menghadapi masa depan. Berdasarkan hasil analisis data diperoleh nilai korelasi $\mathrm{rx} 2 \mathrm{y}=-0,634$ dengan nilai $\mathrm{p}=0,000(\mathrm{p}<0,01)$ hal ini menunjukkan bahwa terdapat hubungan negatif yang sangat signifikan anatara variabel adversity quotient dengan kecemasan menghadapi masa depan. Semakin lemah adversity quotient maka semakin tinggi kecemasan menghadapi menghadapi masa depan yang dimiliki remaja jalanan, begitu pula sebaliknya jika semakin positif adversity quotient yang dimiliki remaja jalanan maka semakin rendah kecemasan menghadapi masa depan remaja jalanan.

Berdasarkan koefisien determinasi diperoleh $\mathrm{R}^{2}$ sebesar 0,356. Hal ini berarti bahwa berarti bahwa konsep diri dan adversity quotient dalam penelitian ini memberikan sumbangan efktif sebesar 35,6\%, artinya kedua variabel ini memberikan pengaruh yang 
cukup signifikan terhadap tingkat kecemasan menghadapi masa depan remaja jalanan. Ketika konsep diri yang remaja jalanan miliki tinggi disertai dengan kemampuannya dalam mengatasi masalah tinggi, maka kecemasan dalam menghadapi masa depan akan rendah. Secara parsial konsep diri memberikan sumbangan efektif sebesar 17,34\% terhadap kecemasan menghadapi masa depan, dan adversity quotient memberikan sumbangan efektif sebesar $26,92 \%$ terhadap kecemasan menghadapi masa depan pada remaja jalanan.

\section{Pembahasan}

Hasil analisis regresi berganda antara konsep diri dan adversity quotient dengan kecemasan menghadapi masa depan menunjukkan adanya hubungan yang sangat signifikan antara konsep diri dan adversity quotient dengan kecemasan menghadapi masa depan pada remaja jalanan. Hasil koefisien korelasi antara konsep diri dengan kecemasan menghadapi masa depan menunjukkan semakin tinggi konsep diri maka akan semakin rendah kecemasan menghadapi masa depan. Hasil koefisien korelasi antara adversity quotient dengan kecemasan menghadapi masa depan menunjukkan semakin tinggi adversity quotient maka akan semakin rendah kecemasan menghadapi masa depan.

Konsep diri merupakan hal penting yang sangat berpengaruh terhadap cara seorang remaja bertindak dan bertingkah laku dalam kehidupan sehari-sehari, baik dalam lingkup sosial maupun pribadinya. Sebagaimana yang dikemukakan oleh Burns (1993) bahwa konsep diri yang positif dapat membantu seseorang untuk meningkatkan kepercayaan terhadap dirinya sehingga dapat memotivasi seseorang untuk menjadi lebih baik lagi.

Santrock (2003) bahwa remaja dapat membuat evaluasi diri terhadap berbagai domain dalam hidupnya, berupa akademik, atletik, penampilan fisik dan lainya. Hal ini dapat berpengaruh terhadap pandangannya terhadap masa depan. Seseorang dengan konsep diri positif dapat mengetahui potensi dalam dirinya, sehingga dapat mengembangkan potensi tersebut demi menggapai masa depannya. Seperti yang dikemukakan oleh Nevid (dalam Nadira \& Zafriel, 2013) bahwa kecemasan berhubungan dengan masa depan, karena kecemasan merupakan kondisi emosi kekhawatiran dan ketakutan individu pada masa yang akan datang.

Konsep diri dapat mempengaruhi cara pandang subjek terhadap dirinya sendiri, dalam segi psikologis, subjek dengan konsep diri yang baik akan mampu menerima dirinya sendiri (kelebihan dan kekurangan) harga dirinya dan hubungannya dengan orang lain. Dengan demikian ia dapat menunjukkan dirinya sebaik mungkin dan menekan kecemasan sehingga ia tidak menarik diri dari lingkungan, tidak merasa kalah dengan orang lain, dan dapat menciptakan hubungan yang baik dengan sekitarnya. Konsep diri dapat menentukan individu memandang masa depannya. Masa depan dapat menjadi hal yang meyakinkan jika individu memiliki gambaran tentang dirinya karena dapat mengetahui dengan baik potensi dan cara untuk mengembangkannya di masa depan, sedangkan masa depan akan menjadi sesuatu yang mengkhawatirkan jika seseorang tidak dapat menciptakan gambaran tentang dirinya di masa depan.

Penelitian sebelumnya yang dilakukan oleh Pramitasari dan Ariana (2014) yang menunjukkan adanya hubungan negatif antara konsep diri fisik dan kecenderungan kecemasan sosial pada remaja awal. Penelitian selanjutnya dilakukan oleh Guntara (2015) menyebutkan terdapat hubungan negatif yang sangat signifikan antara konsep diri dan kecemasan memulai mengerjakan skripsi. Pada variabel tergantung yang digunakan Pramitasari dan Guntara berbeda dengan variabel yang diteliti pada penelitian ini, tetapi hasil dari penelitian tersebut dapat mendukung teori bahwa konsep diri dapat mempengaruhi kecemasan. Hal ini juga didukung oleh teori yang dikemukakan oleh Hjelle (1992) yang mengungkapkan bahwa konsep diri adalah pola pengaturan dari persepsi diri yang dilihat

$5 \quad$ Ira Dwiyati Harahap \& Dessy Pranungsari (Hubungan antara konsep diri dan adversity quotient dengan ...) 
dari diri individu tersebut, terutama gambaran tentang orang seperti apa individu tersebut. Sehingga seseorang yang memiliki konsep diri yang baik akan mampu mengatur gambaran tentang ingin seperti apa dirinya, baik di masa sekarang maupun di masa depan. Individu yang dapat merumuskan masa depannya memungkinkan untuk menekan kecemasan menghadapi masa depan dalam dirinya, sehingga ia akan lebih yakin pada masa depannya.

Selain konsep diri, adversity quotient juga berpengaruh terhadap pembentukan seseorang, sebagaimana yang di katakan oleh Stoltz (2005) bahwa adversity quotient adalah kemampuan seseorang dalam berjuang menghadapi dan mengatasi masalah, hambatan ataupun kesulitan yang dimilikinya, serta mengubahnya menjadi peluang keberhasilan dan kesuksesan. Remaja yang memiliki adversity quotient akan lebih terdorong untuk mengarahkan dirinya pada hasil terbaik dengan upaya optimal memanfaatkan peluang serta aktif dalam bertindak. Apabila seseorang memiliki adversity quotient maka ia dapat dengan baik mengatasi masalah tanpa putus asa, hal ini dikarenakan adversity quotient dapat menentukan sikap individu dalam menghadapi masalah.

Adversity quotient dapat menjadi salah satu faktor yang menekan kecemasan menghadapi masa depan, karena seseorang yang memiliki adversity quotient akan memiliki pengendalian yang baik sehingga mampu megendalikan perilakunya ketika ia dihadapkan dalam situasi yang sulit. Subjek juga akan memiliki daya tahan, sehingga subjek mampu melewati masalah yang akan dihadapi dimasa depan, termasuk ketika subjek mendapat hasil negatif dari usahanya, subjek tidak akan menyerah dan akan lebih bersungguh-sungguh. Sehingga remaja dengan Adversity quotient yang tinggi tidak mengalami kecemasan dalam menghadapi masa depannya, karena ia memiliki daya juang dan kemampuan untuk mengubah hambatan yang dimilikinya menjadi peluang.

Penelitian sebelumnya yang dilakukan oleh Wahyuni (2013) didapatkan hasil bahwa sebanyak 52,94\% tingkat kecemasan remaja jalanan yang tinggal di Liponsos dalam kategori rendah. sebanyak $41,17 \%$ tingkat adversity quotient nya dalam kategori sangat tinggi. Artinya semakin tinggi adversity quotient maka akan semakin rendah kecemasan menghadapi masa depan, sebaliknya semakin rendah adversity quotient maka semakin tinggi kecemasan menghadapi masa depan. Hal ini didukung juga teori yang dikemukakan Sinamo (dalam Supardi, 2013) yaitu adversity quotient dapat didefinisikan sebagai kecerdasan individu dalam menghadapi kesulitan-kesulitan, hambatan-hambatan, maupun tantangan dalam hidup. Dapat dikatakan bahwa seseorang yang memiliki adversity quotient akan mampu mengatasi dan menghadapi kesulitan-kesulitan yang di hadapinya, sehingga ia mampu mengatasi dan mencari solusi atas masalah yang akan dihadapinya pada masa depan.

Uraian di atas menjelaskan bahwa konsep diri dan adversity quotient dapat membantu remaja menyelesaikan tahap perkembangannya, terutama tentang masa depan, Konsep diri dan adversity quotient akan membantu remaja jalanan dalam menghadapi kecemasan menghadapi masa depan, karena memiliki pandangan yang baik pada fisiknya dan juga pengendalian sehingga subjek lebih memahami dirinya sendiri, dan dapat menentukan sikap terhadap pandangan orang lain termasuk terhadap fisiknya. Remaja juga memiliki sikap mampu memperbaiki situasi, hal ini didukung dengan kemampuan mengenal keadaan psikologisnya sehingga memiliki harga diri, kepercayaan diri masa depan, menerima dan memperbaiki situasi tanpa mengurangi kepercayaan diri dan harga dirinya.

Penelitian ini tidak luput dari adanya keterbatasan dan kendala, keterbatasan penelitian ini berupa ketersediaanya subjek penelitian. Hal ini dikarenakan populasi subyek yang semakin sulit ditemukan, subyek kerap kali berpindah tempat dalam kurun waktu yang tidak dapat dipastikan, selain itu, terdapatnya Peraturan Gubernur DIY Nomor 31 Tahun 2012 tentang tata cara penjangkauan anak yang hidup dijalan sehingga keberadaan anak jalanan semakin sulit ditemukan. Selain keterbatasan diatas, terdapat keterbatasan lain yang dihadapi oleh peneliti yaitu tempat pengambilan data yang yang kurang mendukung disaat cuaca hujan karena tempat yang kurang memadai. Keterbatasan lain yang dihadapi peneliti yaitu bahasa dalam sekala penelitian yang kurang dapat dipahami oleh subjek penelitian. 
Selain itu subjek penelitian cenderung merasa bosan pada saat mengisis skala sehingga proses pengisian skala memakan waktu yang cukup lama.

\section{Simpulan}

Beradasarkan hasil analisis data dan pembahasan, dapat diambil kesimpulan bahwa terdapat hubungan negatif yang sangat signifikan antara konsep diri dan adversity quotient dengan kecemasan menghadapi masa depan. Hasil analisis selanjutnya menunjukkan bahwa ada hubungan negatif yang sangat signifikan antara konsep diri dan kecemasan menghadapi masa depan. Semakin tinggi konsep diri maka semakin rendah kecemasan menghadapi masa depan remaja jalanan. Begitu pula kebalikannya, semakin rendah konsep diri maka semakin tinggi kecemasan menghadapi masa depan yang dimiliki remaja jalanan. adversity quotient dengan kecemasan menghadapi masa depan remaja jalanan menunjukkan hubungan negatif yang sangat signifikan. Semakin tinggi adversity quoteint maka semakin rendah kecemasan menghadapi masa depan. Begitu pula sebaliknya, semakin rendah adversity quoteint maka semakin tinggi kecemasan menghadapi masa depan. Bagi peneliti selanjutnya disarankan agar dapat meneliti dan mengembangkan variabel-variabel lain yang dapat memperkaya hasil penelitian mengenai faktor-faktor lain yang dapat mempengaruhi kecemasan menghadapi masa depan yang tidak diungkap dalam penelitian ini.

\section{Daftar Pustaka}

Azwar. S. (2012). Metode penelitian. Yogyakarta: Pustaka Pelajar

Burns, R.B. (1993). Konsep diri (teori, pengukuran, perkembangan dan perilaku). Jakarta: Arcan

Dinas Sosial DIY. (2016). Laporan best practice kegiatan perlindungan anak yang hidup di jalan. Yogyakarta

Guntara, H. (2015). Hubungan antara konsep diri dengan kecemasan memulai mengerjakan skripsi pada mahasiswa Fakultas Psikologi Universitas Muhammadiyah Surakarta. Doctoral dissertation. Universitas Muhammadiyah Surakarta.

Halgin. P. R. (2010). Psikologi abnormal: Perspektif klinis pada gangguan psikologis, Buku 2. Jakarta: Salemba empat

Hjelle, L. A. (1992). Personality theories. Edisi ketiga. New York: McGraw-Hill

Hurlock. E.J. (1993). Perkembangan anak jilid II. Jakarta: Erlangga

Kendal \& Hammen. (1998). Abnormal psychology: Understanding human problems. Second edition. Boston: Houghton Miffin Company

Nadira, A. \& Zafriel, D.M. (2013). Hubungan antara penerimaan diri dan kecemasan menghadapi masa depan pada mahasiswa Fakultas Psikologi Universitas Indonesia. Skripsi. http://lib.ui.ac.id/naskahringkas/2015-09/S45866-Arifa\%20Nadira

Monks, F.J. (2002). Psikologi perkembangan: Pengantar dalam berbagai bagiannya. Yogyakarta: Gajah Mada University Press

Provinsi Daerah Istimewa Yogyakarta. (2012). Peraturan Gubernur (PERGUB) tentang tata cara penjangkauan dan pemenuhan hak anakyang hidup di jalan.

Pramitasari, S. \& Ariana, A. D. (2014). Hubungan antara konsep diri fisik dan kecenderungan kecemasan sosial pada remaja awal. Jurnal Psikologi Klinis dan Kesehatan Mental. 3(1), 48-53. Diunduh 28 Mei 2019 dari journal.unair.ac.id/download-fullpapersjpkk8bf984b7d1full.pdf.

Putro, K.Z. (2017). Memahami ciri dan tugas perkembangan masa remaja. Jurnal Ilmu-ilmu Agama. 17(1), 25-32. Diunduh 28 Mei 2019. ejournal.uinsuka.ac.id/pusat/aplikasia/ article/download

Salkind. J. (2008). Exploring research (6 ${ }^{\text {th }}$ Edition). Pearson Prentice Hall. New Jersey. USA

$7 \quad$ Ira Dwiyati Harahap \& Dessy Pranungsari (Hubungan antara konsep diri dan adversity quotient dengan ...) 
Santrock, J. W. (2003). Adolescence. Perkembangan remaja. Edisi 6. Jakarta: Erlangga

Stotz. G.P. (2000). Adversity quotient. Mengubah hambatan menjadi peluang. Jakarta: Gramedia.

Stoltz, Paul. (2005). Adversity quotient: Mengubah hambatan menjadi peluang. Jakarta: PT. Gramedia.

Supardi, U.S. (2013). Pengaruh adversity quotient terhadap prestasi belajar matematika. Jurnal Formatif, 3(1), 61-71.

Wahyuni, E.S. (2013). Hubungan adversity quotient dengan kecemasan menghadapi masa depan remaja yang tinggal di lingkungan Pondok Sosial (LIPONPES) Wonorejo Surabaya. Character: Jurnal Penelitian Psikologi. 2(1), 1-7. diunduh 28 Mei 2019 dari https://jurnalmahasiswa.unesa.ac.id/index.php/character/article/view/4572. 